\title{
Investigation of a novel cilia-related gene K04F10.2/KIAA0556 in C. elegans
}

\author{
A Sanders ${ }^{*}$, S Cevik, K Kida, R Bowie, O Blacque \\ From First International Cilia in Development and Disease Scientific Conference (2012) \\ London, UK. 16-18 May 2012
}

Multiple proteomics and genomics approaches have been used to identify the molecular parts list of cilia and flagella. However, the specific cilia-related functions of many of these components remain unknown. Previously, K04F10.2 was identified as a candidate cilia-related gene in C. elegans, exhibiting specific expression in ciliated sensory neurons. We now show that GFP-tagged K04F10.2 is highly enriched at the transition zone (TZ) compartment at the base of the ciliary axoneme, and possibly to the more proximal transition fiber/basal body region. Fluorescence microscopy and transmission electron microscopy show that K04F10.2 null mutants possess grossly normal cilium structure and ultrastructure. In contrast, wild-type worms overexpressing a K04F10.2::gfp transgene possess cilium integrity defects such as a dye-filling abnormality (Dyf) and phasmid cilia that are frequently short and abnormally separated. In addition, phasmid neuronal dendrites are abnormally short in these worms. Since GFP-tagged K04F10.2 is enriched at the TZ, we examined possible genetic relationships with known TZ-associated ciliary disease genes such as those causing Meckel-Gruber syndrome (MKS) and Nephronophthisis (NPHP). Unlike the synthetic Dyf (SynDyf) phenotypes known for alleles of various MKS and NPHP genes, no such phenotype was observed in K04F10.2;mks-5 and K04F10.2;nphp-4 double mutants. However, K04F10.2 was found to synthetically interact (SynDyf) with Joubert syndrome-associated Arl13b/arl-13, which interestingly does not localise at the TZ. Together, these data implicate K04F10.2 as a novel TZ-enriched protein with functions that are distinct from canonical MKS and NPHP module components.

Published: 16 November 2012 * Correspondence: aawmsanders@gmail.com
University College Dublin, Ireland

C 2012 Sanders et al; licensee BioMed Central Ltd. This is an Open Access article distributed under the terms of the Creative Commons Attribution License (http://creativecommons.org/licenses/by/2.0), which permits unrestricted use, distribution, and reproduction in any medium, provided the original work is properly cited.
doi:10.1186/2046-2530-1-S1-P43

Cite this article as: Sanders et al: Investigation of a novel cilia-related gene K04F10.2/KIAA0556 in C. elegans. Cilia 2012 1(Suppl 1):P43.

Submit your next manuscript to BioMed Central and take full advantage of:

- Convenient online submission

- Thorough peer review

- No space constraints or color figure charges

- Immediate publication on acceptance

- Inclusion in PubMed, CAS, Scopus and Google Scholar

- Research which is freely available for redistribution
C Biomed Central 